\section{COMPROMISO ASUMIDO}

Se cierra un año estupendo para nuestra querida Sociedad Paraguaya de Cirugía, un año con gran satisfacción para todos los cirujanos de nuestro país, así como para los estudiantes de medicina y para las sociedades afines a la carrera de ciencias médicas. Prueba de ello han sido los más de 1.400 inscriptos -record absoluto- a nuestro mayor evento científico, el XVIII Congreso Paraguayo de Cirugía. Un evento con figuras de talla mundial, que han compartido sus experiencias en el campo quirúrgico y sus lazos de confraternidad para con nosotros, haciéndonos notar lo valioso de nuestra calidez humana, y a la vez la calidad científica de nuestro trabajo.

Complementando a este magno evento, las jornadas científicas realizadas en la capital y el interior del país, han tenido un éxito rotundo, lo cual solo nos indica que hemos hecho bien lo propuesto, y que debemos seguir avanzando en ofrecer a nuestros miembros lo mejor para la continua formación de postgrado.

El 2017 será un año lleno de magnificas actividades organizadas por la Comisión Directiva, que espero, llene sus expectativas, pues es el compromiso que hemos asumido con la finalidad de engrandecer a nuestra tan amada Sociedad y a sus asociados.

En nombre de la Comisión Directiva, les deseo un excelente cierre de año y abundante bonanza en el 2017.

iiiFelices Fiestas!!!

\section{ASSUMED COMMITMENT}

A great year ends for our dear Paraguayan Society of Surgery, a year with a lot of satisfaction for all surgeons in our country as well as for medical students and for societies related to medical science career. Proof of this are more than 1,400 inscribed -absolute record- to our greatest scientific event, the 18th Paraguayan Congress of Surgery. An event with world-class figures, who have shared their experiences in the surgical field and made as feel like a worldwide family, making us aware of the value of our human warmth and the scientific quality of our work.

Complementing this great event, scientific conference held in the capital and the provinces, have had a resounding success, which only tells us that we have done well, and we must move forward to offer our members the best for continuous postgraduate training.

Our commitment is that the year 2017 will be a year full of amazing activities organized by the Board, tol fill your expectations, in order to honor our beloved Society and its partners.

On behalf of the Board, I wish you a Merry Christmas and best wishes for 2017 .

Dr. Agustín Rodríguez

Dr. Agustín Rodríguez 